\title{
Oral ulcer due to dabigatran capsule
}

\author{
Yasumasa Kuno, ${ }^{1}$ Shinichi Miyazaki, ${ }^{1}$ Yusuke Saito, ${ }^{2}$ Takuya Ikeda ${ }^{1}$
}

${ }^{1}$ Department of Pulmonary Medicine, Yokkaichi Municipal Hospital, Yokkaichi, Mie, Japan ${ }^{2}$ Department of Pharmacy, Yokkaichi Municipal Hospital, Yokkaichi, Mie, Japan

Correspondence to Dr Shinichi Miyazaki, miyazaki.sin1@gmail.com

Accepted 15 September 2018

Check for updates

(C) BMJ Publishing Group Limited 2018. No commercial re-use. See rights and permissions. Published by BMJ.

To cite: Kuno Y, Miyazaki S, Saito Y, et al. BMJ Case

Rep Published Online First: [please include Day Month Year]. doi:10.1136/bcr-2018227401

\section{DESCRIPTION}

An 80-year-old man with cerebral infarction and no neurological deficits was hospitalised for right empyema. Although the patient's condition improved with antimicrobial therapy and right thoracic drainage, a swelling in his right cheek was observed during clinical rounds. Oral examination revealed ulceration on the right buccal mucosa (figure 1A) with an embedded blue solid matter (figure 1B), which was removed. After confirming the history of prescribed medications, the removed matter was determined to be a dabigatran capsule (figure 1C), and oral ulcer due to dabigatran was suspected. With conservative measures, re-epithelialisation was achieved within 2 weeks.

Dabigatran is currently used as an alternative to warfarin for venous thromboembolism

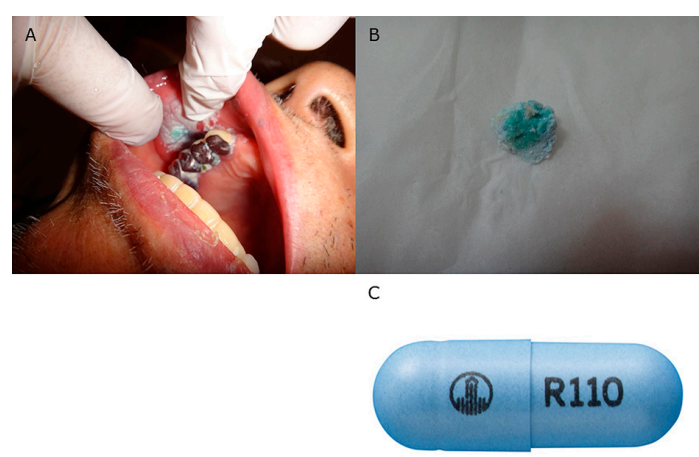

Figure 1 (A) Oral ulcer on the right buccal mucosa, (B) the removed solid matter, (C) the dabigatran capsule. and non-valvular atrial fibrillation. Dabigatran is formulated with tartaric acid, the acidity of which increases drug absorption. ${ }^{1}$ Although we did not perform a component analysis for the removed matter, exposure of the oral cavity to a strong acid from the dabigatran capsule was the likely cause of the oral ulcer in the current patient. Given that vascular dementia and swallowing problems are common in the elderly, prescribing dabigatran to these patients should be reconsidered.

\section{Learning points}

- Dabigatran capsule may cause oral ulcer due to its strong acidity.

- Prescribing dabigatran in patients with vascular dementia and swallowing problems should be reconsidered.

Contributors YK: reviewed the patient, performed the literature review and wrote the manuscript. SM: involved in critical revision of the work. YS and TI: supervised the project.

Funding The authors have not declared a specific grant for this research from any funding agency in the public, commercial or not-for-profit sectors.

Competing interests None declared.

Patient consent Obtained.

Provenance and peer review Not commissioned; externally peer reviewed.

\section{REFERENCE}

1 Stangier J, Stähle H, Rathgen K, et al. Pharmacokinetics and pharmacodynamics of the direct oral thrombin inhibitor dabigatran in healthy elderly subjects. Clin Pharmacokinet 2008;47:47-59.

Copyright 2018 BMJ Publishing Group. All rights reserved. For permission to reuse any of this content visit

http://group.bmj.com/group/rights-licensing/permissions.

BMJ Case Report Fellows may re-use this article for personal use and teaching without any further permission.

Become a Fellow of BMJ Case Reports today and you can:

- Submit as many cases as you like

- Enjoy fast sympathetic peer review and rapid publication of accepted articles

- Access all the published articles

- Re-use any of the published material for personal use and teaching without further permission

For information on Institutional Fellowships contact consortiasales@bmjgroup.com

Visit casereports.bmj.com for more articles like this and to become a Fellow 